\title{
Seasonal variability of the advective transport of particulate matter and organic carbon in the Gulf of Lion (NW Mediterranean)
}

\author{
Agnès LAPOUYADE, Xavier DURRIEU DE MADRON* \\ UMR5110, CNRS-University of Perpignan, CEFREM, 52, avenue de Villeneuve, 66860 Perpignan cedex, France
}

Received 28 August 2000; revised 12 February 2001; accepted 20 February 2001

\begin{abstract}
Nine hydrographic cruises were performed on the Gulf of Lion continental margin between June 1993 and July 1996. These observations are analysed to quantify the fluxes of particulate matter and organic carbon transported along the slope by the Northern Current and to characterise their seasonal variability. Concentration of particulate matter and organic carbon are derived from light-transmission data and water sample analyses. The circulation is estimated from the geostrophic current field. The uncertainty on the transport estimate, related to the error on the prediction of particle concentrations from light-transmission data and the error on velocities, is assessed. The particulate matter inflow entering the Gulf of Lion off Marseille is comparable to the Rhône River input and varies seasonally with a maximum transport between autumn and spring. These modifications result from variations of the water flux rather than variations of the particulate matter concentration. Residual transports of particulate matter and organic carbon across the entire Gulf of Lion are calculated for two cruises enclosing the domain that were performed in February 1995 and July 1996. The particulate matter budgets indicate a larger export from the shelf to deep ocean in February $1995\left(110 \pm 20 \mathrm{~kg} \mathrm{~s}^{-1}\right)$ than in July $1996\left(25 \pm 18 \mathrm{~kg} \mathrm{~s}^{-1}\right)$. Likewise, the mean particulate organic carbon export is $12.8 \pm 0.5 \mathrm{~kg} \mathrm{~s}^{-1}$ in February 1995 and $0.8 \pm 0.2 \mathrm{~kg} \mathrm{~s}^{-1}$ in July 1996. This winter increase is due to larger allochthonous and autochthonous inputs and also to enhanced shelf-slope exchange processes, in particular the cascading of cold water from the shelf. The export of particulate matter by the horizontal currents is moreover two orders of magnitude larger than the vertical particulate fluxes measured at the same time with sediment traps on the continental slope. () 2001 Ifremer/CNRS/IRD/Éditions scientifiques et médicales Elsevier SAS
\end{abstract}

Résumé - Variabilité du transport advectif de matériel particulaire et de carbone organique dans le golfe du Lion (Méditerranée nord-ouest). Neuf campagnes hydrologiques ont été exécutées sur la marge continentale du golfe du Lion entre juin 1993 et juillet 1996. Ces observations sont analysées pour quantifier les flux de matière et de carbone organique particulaires transportés par le Courant nord, le long de la pente continentale, et pour caractériser leur variabilité saisonnière. Les concentrations en matière et en carbone organique particulaires sont déduites de mesures optiques de transmission et de l'analyse d'échantillons d'eau. La circulation est estimée à partir du champ de courant géostrophique. L'incertitude sur le transport, liée à l'erreur sur la prévision de la concentration en particules et à l'erreur sur les vitesses, est évaluée. Le flux de matière particulaire entrant dans le golfe du Lion au large de Marseille est comparable au flux solide du Rhône et présente un flux maximum entre l'automne et le printemps. Ces modifications résultent des variations du flux d'eau plutôt que de celles de la concentration en particules. Les transports résiduels de la matière et du carbone organique particulaires sont calculés pour deux campagnes englobant l'ensemble du golfe et réalisées en février 1995 et juillet 1996. Les budgets de matière particulaire indiquent une plus grande exportation en février $1995\left(110 \pm 20 \mathrm{~kg} \mathrm{~s}^{-1}\right)$ qu'en juillet $1996\left(25 \pm 18 \mathrm{~kg} \mathrm{~s}^{-1}\right)$. De même, l'exportation de carbone organique particulaire est de 12,8 $\pm 0,5 \mathrm{~kg} \mathrm{~s}^{-1}$ en février 1995 et de $0,8 \pm 0,2 \mathrm{~kg} \mathrm{~s}^{-1}$ en juillet 1996. Cette différence est due à une

*Correspondence and reprints: fax: +33468662096 .

E-mail address: demadron@univ-perp.fr (X. DURRIEU DE MADRON).

(C) 2001 Ifremer/CNRS/IRD/Éditions scientifiques et médicales Elsevier SAS. Tous droits réservés

S0399178401011483/FLA 
intensification hivernale des apports allochtones et autochtones et, également, des échanges entre le plateau et la pente sous l'effet, en particulier, des plongées d'eau froide. L'exportation de la matière particulaire par les courants horizontaux est, de deux ordres de grandeur plus importante que les flux particulaires verticaux mesurés sur la pente continentale, aux mêmes périodes avec des pièges à particules. () 2001 Ifremer/CNRS/IRD/Éditions scientifiques et médicales Elsevier SAS

\section{advective transport / budget / Gulf of Lion / organic carbon / particulate matter}

\section{transport advectif / bilans / golfe du Lion / matière particulaire / carbone organique}

\section{INTRODUCTION}

\subsection{Transport of matter on continental margins}

Continental margins represent less than $20 \%$ of the world's ocean surface area, but they are a special interface between ocean, continent and atmosphere. The high biological productivity of the continental margin due to nutrient inputs from land, coastal upwelling and terrigenous inputs of organic matter, makes this zone the site of a high concentration of deposited organic matter. Besides this deposition, margins export particulate and dissolved organic matter to the deep sea Bauer and Druffel. 1998 Liw et_al_2000) A good knowledge of the fluxes of organic matter between the shelf region and the deep sea is necessary to develop models and budgets on the world scale; this is one of the major aims of the Joint Global Ocean Flux Studies and Land Ocean Interactions in the Coastal Zone programmes Hall and Smith. 1996.

Exchanges of matter at the shelf edge generally result from various transport processes. Huthnance (1995) reviewed the different mechanisms (coastal, slope and boundary currents, eddies, tides, fronts, cascading, upand down-welling, etc) occurring on the world's continental margins. The author pointed out the important role of the strong currents flowing along the continental slope (boundary currents), which are quasi-permanent feature of the margins' circulation.

\subsection{Shelf-slope exchanges in the Gulf of Lion}

The continental margin of the Gulf of Lion in the NW Mediterranean Sea (fgure $)$ receives large amounts of matter supplied by several rivers, particularly the Rhône River (Pont. 1997) and is one of the most biologically productive regions of the western Mediterranean More and André.1991]. Various studies using molecular tracers Bouloubassi et al., 1997) stable elements (Henry et al. 1994) or radionuclides Calmet and Fernandez, 1990; Heussner et al__1990 provided evidence of a lateral advective transfer of dissolved and particulate matter delivered by the Rhône River towards the adjacent North-Balearic basin.

Vertical fluxes of particulate matter (PM) and particulate organic carbon (POC) have been quantified by sediment traps on different parts of the slope (Monaco et al. 1990 and 1999: Heussner et al. 1996). These measurements clearly showed an export of shelf material on the western part of the shelf. On the other hand, the horizontal fluxes of matter have been less studied. Some experimental work estimated the global transport of dissolved substances off Marseille Goro et al. 1997: Conan et al. 1998) and a modelling study simulated the year-long advective exchanges of water and nutrients TusseauVuillemin et al. 1998). There is no experimental quantification of the present export by advection of PM and POC from the shelf to the deep basin. Only coarse sedimentary budgets estimated the exchanges over long (100-10 000 years) time scales Can_and_Aloisi_1990. Zuretal. 1991, 1997.

A cyclonic along-slope circulation characterises the general circulation in the Gulf: the Liguro-Provençal or Northern Current (figure - 1). This current is a permanent and well-documented feature of the NW Mediterranean circulation (Millot, 1990 and references therein; Conan and Millot, 1995; Beckers et al, 1997; Hauser et al. 2000. Several studies took an interest in the effects of this circulation and other mechanisms on the off-shelf export of particulate matter. Durrieu de Madron and Panouse (1996) emphasised the effect of the cyclonic circulation of the outer shelf and the winter cascading of cold dense water on the near-bottom transport of PM. Durriel_de Madron et al_(1990) showed that the PM standing stock on the slope increased towards the south 


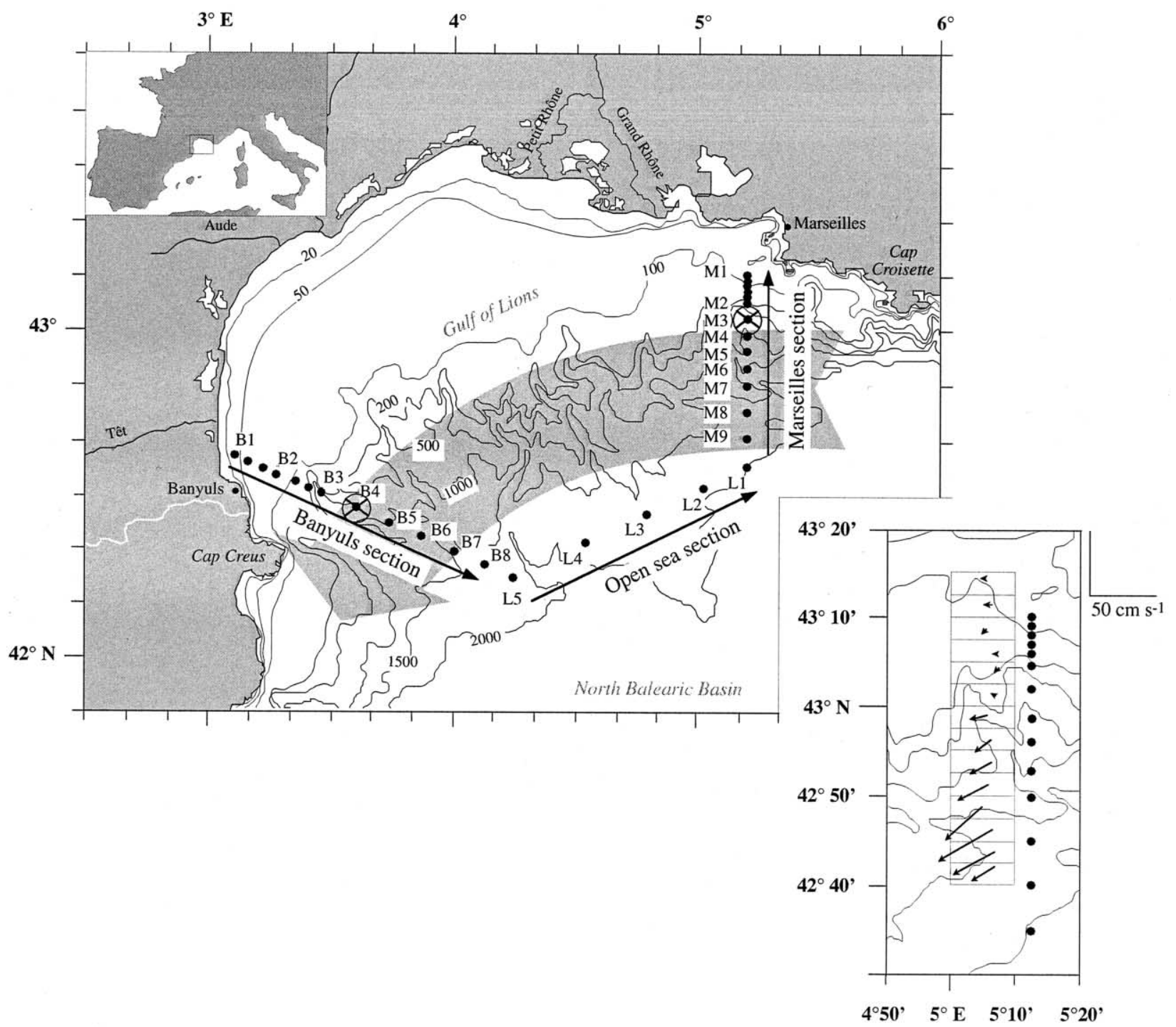

Figure 1. Bathymetry of the Gulf of Lion and CTD stations locations occupied during the SuiviLion 12 and Billion cruises. The other cruises on the Marseille section occupied stations M1 to M7. Crosses: location of the two moorings in the Planier Canyon off Marseille and the Lacaze-Duthiers Canyon off Banyuls; grey arrow: path and width of the Northern Current along the continental slope; inset: mean current measured with the acoustic doppler current profiler (ADCP) of the RV Tethys II off Marseille. Measurements were obtained from November 1997 to May 2000 , and analysed by Semantic TS. All vectors are averaged horizontally within each sector (10' longitude and 2.5 ' latitude) and vertically between 8 and $244 \mathrm{~m}$ depth.

west, and that the part moving seaward was swept along the slope by the Northern Current. Finally, Durrieu de Madron et al. (1999) stressed the effect of the variability (meandering motions) of this circulation on the crossslope transport of PM.

The main objective of the present work is to quantify the import or export of PM and POC by advective transport between the Gulf of Lion and the adjacent North Balearic basin. A significant seasonal variability is expected since the hydrology and the circulation (Millot. 1990; Beckers et al. 1997) as well as the vertical fluxes of PM (Monaco et al. 1990. 1999) display a clear annual signal with contrasted winter and summer characteristics. This work further aims at characterising the seasonal variability of the PM advective transport. 
Table I.

\begin{tabular}{ll}
\hline Cruises & Dates \\
\hline SuiviLion 3 & 19-20 June 1993 \\
SuiviLion 5 & 19 October 1993 \\
SuiviLion 8 & 2 May 1994 \\
SuiviLion 9 & 27 June 1994 \\
SuiviLion 10 & 27 August 1994 \\
SuiviLion 11 & 14-15 November 1994 \\
SuiviLion 12 & 8-15 February 1995 \\
Euromarge 95 & 21-22 June 1995 \\
Billion & 2-5 July 1996 \\
\hline
\end{tabular}

\section{METHODS}

\subsection{Field experiment}

The sampling strategy took advantage of the presence of the permanent Northern Current along the continental slope. If an export of matter occurs from the shelf to the deep basin, the water advected along the slope by the boundary current will be enriched in that material and the corresponding transport will increase downstream. We selected two cross-slope transects to characterise the NE inflow and the SW outflow (figure - ). The comparison of the advective inflows and outflows of matter across the limits of the margin permits the quantification of the export from the Gulf of Lion margin if a downstream transport is measured (or the reverse otherwise).

Nine oceanographic cruises were performed between June 1993 and July 1996 (table to sample two cross-slope transects: one off Marseille (stations M1 to M7) at the northeastern limit of the Gulf of Lion and a second off Banyuls (station B1 to B5) at its southwestern limit (Goure _ - During the last two cruises, 'SuiviLion 12' (February 1995) and 'Billion' (July 1996), the network of stations was extended seaward and connected by an offshore section (stations L1 to L5) in order to encompass the width of the Northern Current and to enclose the gulf. The domain circumscribed by the whole section, which included the shelf and the slope down to $2000 \mathrm{~m}$ depth, will be referred to hereafter as the Gulf of Lion.

Conductivity, temperature, and pressure data were measured between the surface and the bottom with a SeaBird 9/11 CTD probe. Transmissometry data was measured with a $0.25 \mathrm{~m}$ pathlength Seatech transmissometer at wavelength $660 \mathrm{~nm}$. Density was derived from the concentration-temperature-depth (CTD) data according to the international equation of state (EOS80). Raw data were averaged every $5 \mathrm{dbar}\left(=5 \times 10^{4} \mathrm{~Pa}\right)$.

Current meters (Aanderaa rotor type) and sediment traps (model PPS3 Technicap) were moored next to stations B4 and M3 to assess the seasonal variability of currents and vertical particulate fluxes on the Marseille and Banyuls sections. Each mooring line was deployed at $1000 \mathrm{~m}$ and was equipped with two trap-current meter pairs, the first pair at $35 \mathrm{~m}$ above the bottom and the second pair at around $500 \mathrm{~m}$ above the bottom. Current meters were located $5 \mathrm{~m}$ below the sediment traps.

\subsection{Particulate matter calibration}

Beam attenuation coefficient (BAC or $c$ ), expressed per meter, was deduced from light transmission measurements $(T r$, in percent) and pathlength $(L=0.25 \mathrm{~m})$, by the relationship: $c=-1 / L \ln (T r)$. The BAC is the sum of the attenuation coefficient of particles $\left(c_{\mathrm{p}}\right)$ and the attenuation coefficient of pure water $\left(c_{\mathrm{w}}\right): c=c_{\mathrm{p}}+c_{\mathrm{w}}$. The value of $c_{\mathrm{w}}$ is assumed to be the minimum BAC value measured during the cruises (i.e., $c_{\mathrm{w}}=0.351 \mathrm{~m}^{-1}$ ).

Along with CTD/transmissometry profiles, twenty two water samples were made during three winter and summer cruises in intermediate and bottom nepheloid layers with Niskin bottles mounted on a rosette. The water samples (between 1.5 and $3 \mathrm{~L}$ ) were filtered up to filter saturation on pre-weighed Nuclepore filters of $0.4 \mu \mathrm{m}$ pore size. Their solid residue weights yielded accurate PM concentrations (Feely et al. 1991). POC, as well as PM, was measured by filtration on precombusted Whatman GF/F filters of $0.7 \mu \mathrm{m}$ mean pore size and by combustion of the latter filter in a CS 125 Leco analyzer, after acidification by $\mathrm{HCl} 2 \mathrm{~N}$ to remove carbonates Cawwet 1981. POC content (in percent) was then calculated as the ratio of POC and PM concentrations. Triplicate water samples were analysed in order to assess the experimental uncertainty and eliminate spurious measurements.

All valid triplicate measurements of PM concentration $\left(C_{\mathrm{PM}}\right)$ and corresponding $\mathrm{BAC}$ were averaged. A significant correlation was obtained between the BAC and the PM concentrations for the sets of samples collected at different seasons. An analysis of covariance indicated 


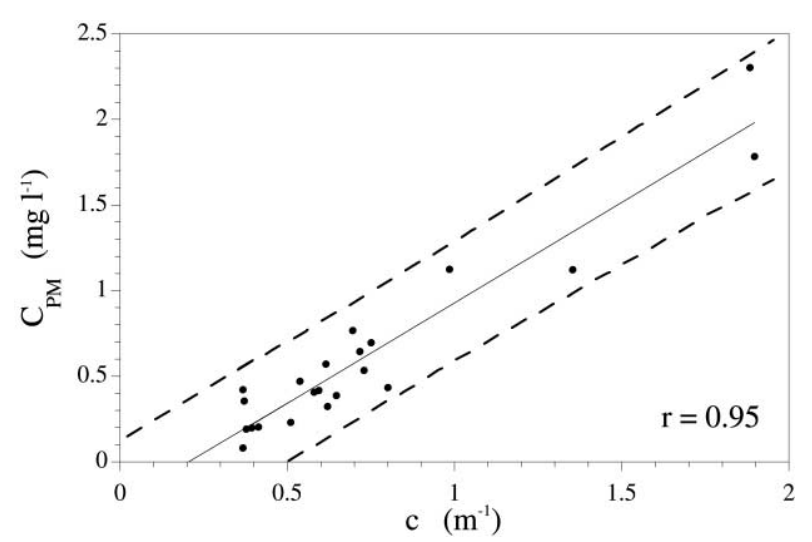

Figure 2. Calibration of particulate matter concentrations $\left(C_{\mathrm{PM}}\right)$ versus beam attenuation coefficient $(c)$. The solid line indicates the least square regression, the dashed lines indicate the $95 \%$ prediction limits of the regression.

that no significant difference appeared between the least square regressions for each data set. Consequently, a single predictive linear relationship was computed for the whole set of data:

$C_{\mathrm{PM}}=1.17 c-0.24$ where $C_{\mathrm{PM}}$ is expressed in milligrams per litre and $c$ per metre (figure 2). The correlation coefficient $r$ was 0.95 . The error on the estimated values of $C_{\mathrm{PM}}$ was estimated by the $95 \%$ prediction limits Soka and Rohlf.1981.

The linear relationship was valid for near-bottom and mid-depth waters, where the particle size and characteristics are generally more homogenous than in surface waters. Nevertheless, using the same type of instruments on the nearby Barcelona continental margin, Puig and Ealanques (1998) compared the correlation of beam attenuation coefficient with surface and mid-depth/near bottom particulate matter concentrations. Though the surface measurements were more dispersed than the deeper measurements, the BAC was significantly correlated with the particulate matter concentrations and the linear regressions of both data sets were comparable. Furthermore, Guillén et al_(2000) made a compilation of all light-transmission calibrations performed in the northwestern Mediterranean, including those of Puig and Ealanques (1998) as well as ours. They derived a common and significant linear relationship for all data sets, which was close to that obtained with our data. In the context of the present work, it appeared satisfactory to apply our linear relationship to the entire water column.
No predictive relationship could be inferred between POC concentrations and BAC because they were not significantly correlated. However, for the present study, it is possible to use the POC content to estimate POC concentration from the predicted PM concentration. The compilation of 529 POC measurements obtained at various seasons and at all depths in the Gulf of Lion and its adjacent basin showed that POC concentrations and contents vary with season and depth (figure 3). We computed the vertical distribution of the median POC content and the median POC concentration during the winter (November-May) and summer (May-October) periods. The observations were pooled in different depth bins to get ensembles with enough observations $(>10)$. We obtained thus a higher resolution in the surface layer than in the deeper layers. We did not observe any significant differences between the shelf and slope region (down to $1000 \mathrm{~m}$ depth) and open sea.

In summer, the POC content showed a maximum (15\%) around $40 \mathrm{~m}$ depth and a secondary maximum (7\%) around $80 \mathrm{~m}$ depth, which is the lower limit of the thermocline. In winter, the median POC content in the surface layer (0-40 m) was more mixed and higher (22\%) than in summer. The POC content was minimum (3\%) around $100 \mathrm{~m}$ depth as POC concentration (Goure $3 \mathrm{~b}$ ) whatever the season, because of the higher concentration of lithogenic particles found in the bottom nepheloid layer on the outer shelf and the intermediate nepheloid layer that detached from the shelf break. The POC content below $100 \mathrm{~m}$ depth ranged from 3 to $5 \%$ in summer, and from 8 to $10 \%$ in winter.

\subsection{Calculation of the advective transport}

The advective fluxes of matter were obtained by integration of the product of $C_{\mathrm{PM}}$ with current velocity, over the water column depth and distance along track. Currents were calculated from CTD data using the geostrophic approximation of the equations of movement (Pond and Pickard, 1983)

The station spacing ranged between 3 and $13 \mathrm{~km}$ for the cross-slope sections and between 17 and $26 \mathrm{~km}$ for the offshore section. The distances for the cross-slope section were generally smaller than the internal radius of deformation; which ranges between 8 and $11 \mathrm{~km}$ according to the seasons Grilli_and Pinardi_1998) which means that the horizontal density gradients were well described. On 
A)

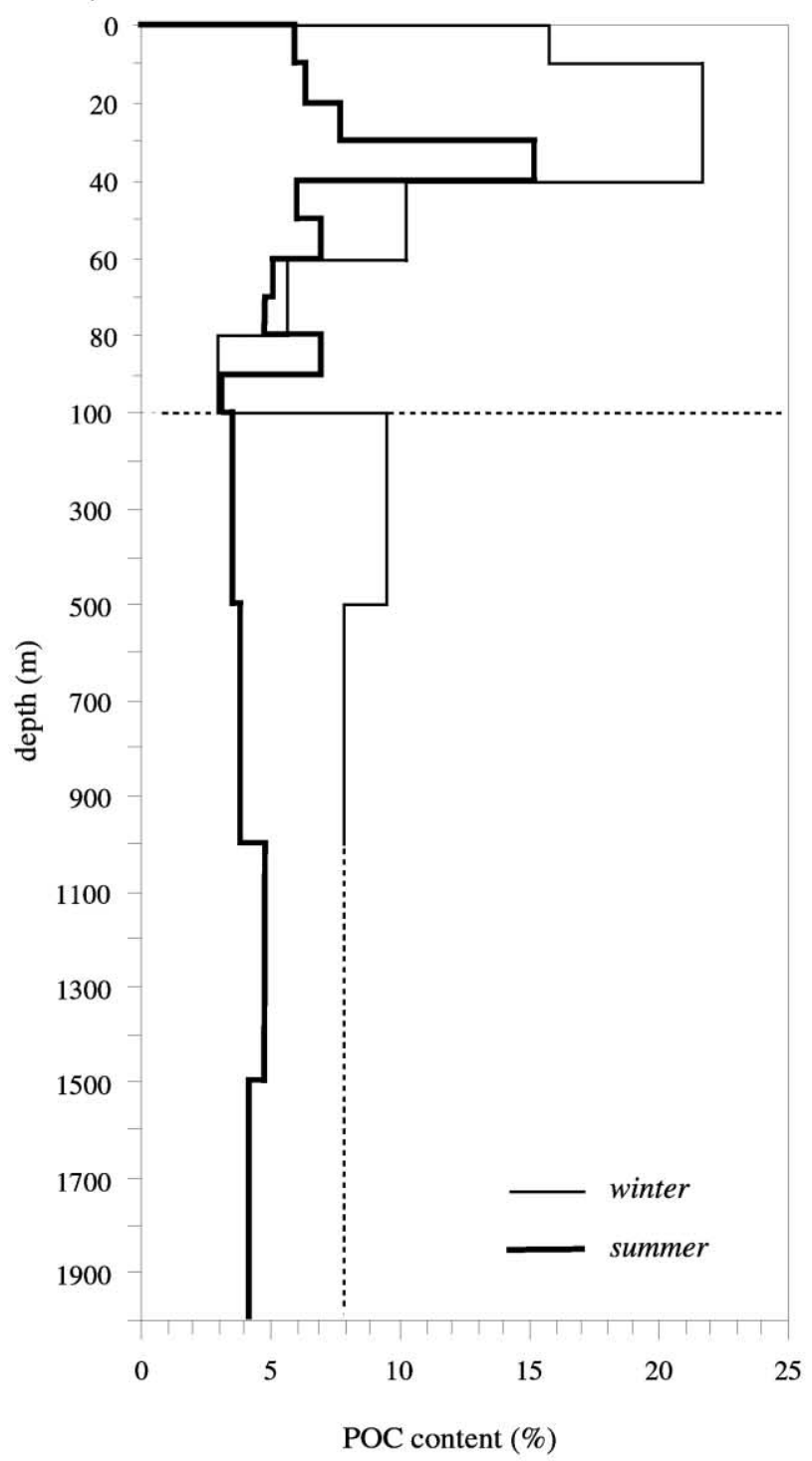

B)

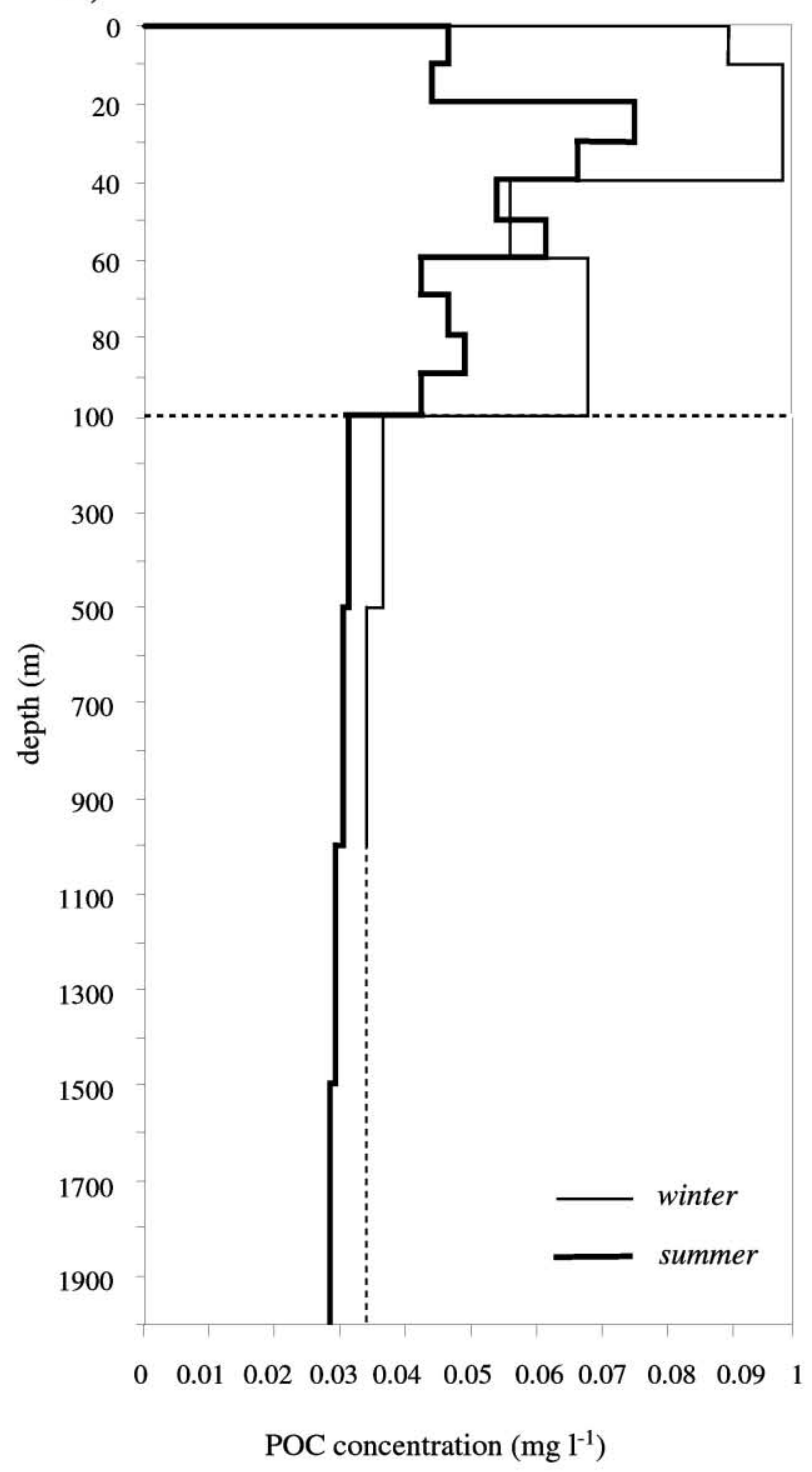

Figure 3. Vertical distribution of POC content (A) and vertical distribution of POC concentration (B) for two hydrological seasons: winter (November-May) and summer (June-October). The median value of the POC content is calculated for depth bins of 10-40 m in the surface layer $(<100 \mathrm{~m})$ and depth bins of $500 \mathrm{~m}$ for the deeper layer. Note the change of vertical scale between the surface and deep layers. No data were available below $1000 \mathrm{~m}$ depth in winter.

the other hand, the horizontal density gradients estimated along the offshore section were probably smoother and the resulting geostrophic velocities were lower than in reality. Since most of the transport, associated to the Northern Current, occurs through the cross-slope sections, the underestimation of the flow intensity across the off-shore section has probably a small effect on the overall transport of water and PM.

In order to estimate the velocities for each pair of stations whose depth varied strongly along the section, absolute geostrophic velocities were related to a refer 
ence velocity that was calculated according to the inverse method of Hofman and Worley (1986). This method aimed at minimising the residual water transport (difference between the inflow and the outflow) within potentially conservative layers.

As shown in the results, we discriminated four water masses from their thermo-haline characteristics in the Gulf of Lion, namely, the surface Modified Atlantic Water (MAW), the Winter Intermediate Water (WIW), the Levantine Intermediate Water (LIW) and the Deep Western Mediterranean Water (DWMW) (figure 4). For the inverse computation, we had to choose layers for which the exchanges between themselves could be assumed negligible. The strong mixing that occurred on the shelf and at the shelf-break during wintertime, primarily affected the MAW on the shelf, and both the MAW and the WIW on the upper-slope and offshore. For that reason, we merged these two water masses to form one single surface layer. Isopycnal surfaces, expressed in terms of potential density anomaly $\left(\sigma_{\theta}\right)$, were used to separate the three water mass layers. The lower limit of the surface layer was defined by the 29.0 isopycnal, which reached $250 \mathrm{~m}$ depth close to the slope and rose to about $100 \mathrm{~m}$ depth offshore. This layer encompassed thus the shelf and the upper slope waters and the exchanges between this layer, and the underlying LIW water could reasonably be neglected. The limit separating the intermediate (LIW) and deep (DWMW) layers was the 29.09 isopycnal.

An initial reference level was determined for the SuiviLion12 and Billion cruises - which enclosed the gulf - by seeking the level of no motion that minimises the residual water transport in all three layers. For this empirical search, an a priori zero velocity was considered at the deepest common level of the station pairs above the reference level. The residual flux vanished for a reference level at $775 \mathrm{~m}$ for SuiviLion 12 and at $1072 \mathrm{~m}$ for Billion. The water transport imbalance for each layer ranged between $0.002 \times 10^{6}$ and $0.27 \times 10^{6} \mathrm{~m}^{3} \mathrm{~s}^{-1}$. Using the initial velocity field, barotropic correction velocities (at each stations pair) were then deduced by imposing water flux conservation constraints for the three water mass layers. This linear least squares problem used an inverse square root weighting Hofman and Worley 1986) to adjust flow preferentially on the slope and the shelf where the strongest corrections are expected. The inversion procedure used the singular value decomposition method.
The correction velocities for the deep stations were small, i.e., of the order of $0.5 \mathrm{~cm} \mathrm{~s}^{-1}$. Large corrections, up to $6 \mathrm{~cm} \mathrm{~s}^{-1}$, were found along the slope and on the shelf. For both cruises, we compared the computed currents with contemporary monthly mean currents at 500 and $1000 \mathrm{~m}$ depth. Taking into account the uncertainty of the observations, the computed currents and the measured averaged currents were comparable. We also made a comparison with non contemporary observations in the surface layer. The intensity and direction of the computed currents within the core of the Northern Current off Marseille were consistent with near-surface mean currents measured in the vicinity of the section with moored current meters in 1988-1989 (Durrieu de Madron et al. 1999) and shipborne ADCP measurements obtained since 1997 (Hauser et al, 2000 and average current plotted in foure (3). All these measurements indicated an alongslope current with a westward velocity component ranging between 10 and $40 \mathrm{~cm} \mathrm{~s}^{-1}$. The amplitude of the computed and observed currents on the shelf was also comparable. Observed mean currents on the shelf ranged between 2 and $6 \mathrm{~cm} \mathrm{~s}^{-1}$ (average currents plotted in figure (7).

\subsection{Evaluation of uncertainties}

The calculation of particulate matter concentration from beam attenuation coefficient as well as the computation of velocities were contaminated by errors which affected the transport estimates.

We used a Monte Carlo method (Press et_al,_1989) to assess the uncertainties on water transport linked to the velocity errors, and particulate transport linked both to the particulate concentration and velocity errors. For each measurement of particulate attenuation coefficient, the corresponding optimum concentration (estimated by the linear relationship) was corrupted by a random deviate. We chose a normally distributed deviate centred around the predicted concentration (Ggure 2), with a standard deviation corresponding to half the aforementioned prediction interval of the regression (for a normal distribution, $95 \%$ of the population is contained within approximately 2 standard deviations on both sides of the mean). For velocity, we assumed that the deviate was normally distributed with a standard deviation equal to $\pm 20 \%$ of the current velocity. This limit was inferred from observations. It characterised the coefficient of variation (standard deviation $/$ mean $\times 100$ ) of the current measured 

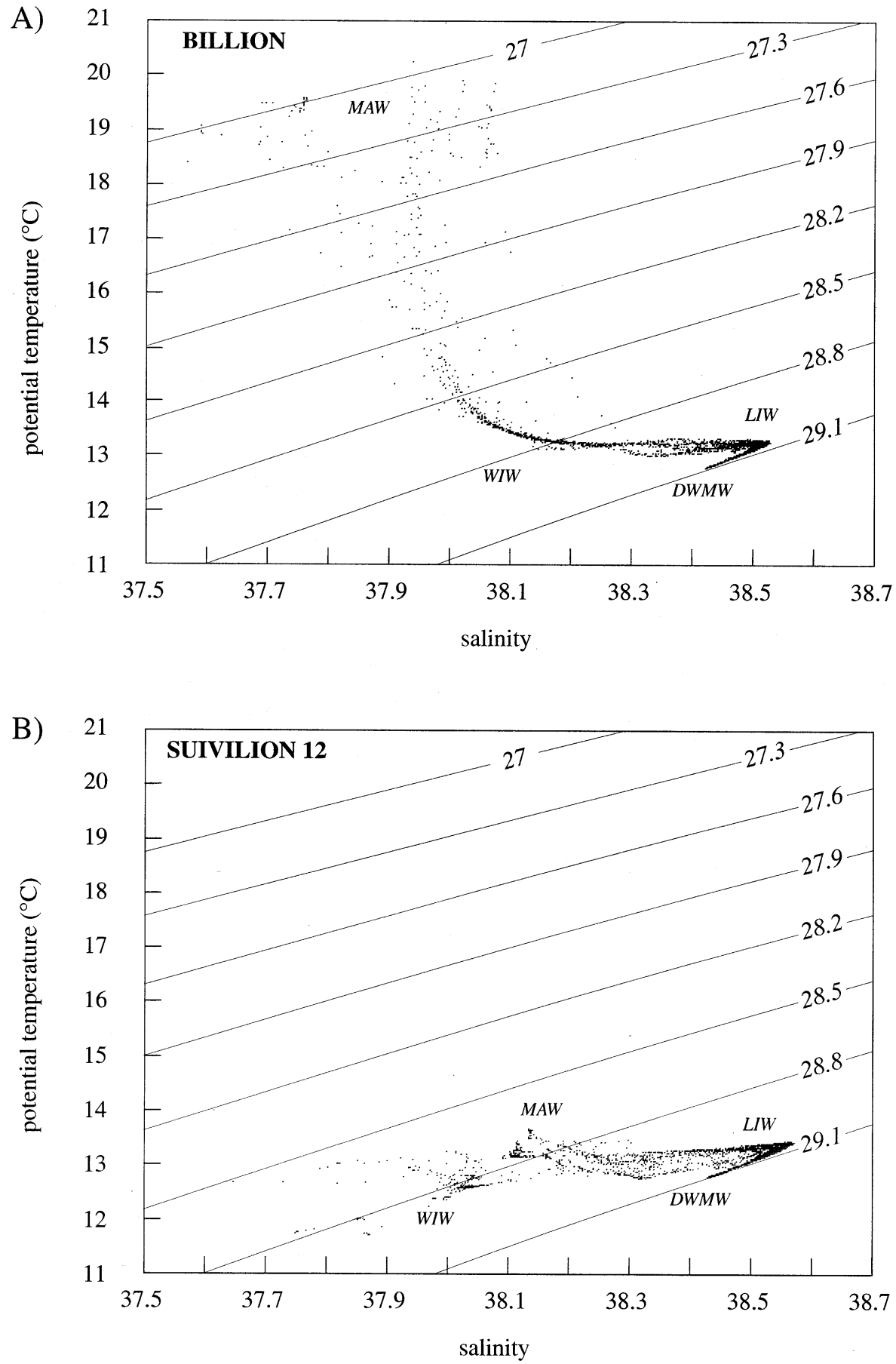

Figure 4. Potential temperature-salinity diagrams during the Billion cruise in July 96 (A) and the SuiviLion 12 cruise in February 1995 (B). Isolines represent potential density anomalies. Four water masses are detected: Modified Atlantic Water: MAW, Winter Intermediate Water: WIW, Levantine Intermediate Water: LIW, Deep Western Mediterranean Water: DWMW.

within the core of the Northern Current off Marseille (Goure $)$. The generation of random deviates used various techniques described in Press et al. (1989) A thousand different simulations of PM transport across the Marseille section or the closed section were performed for the different cruises. For each of them, water and PM 
mean transports and their standard deviation were estimated from this ensemble of trials.

We used the median POC content and the particulate matter flux within each depth bin to compute the POC flux. The uncertainty on the POC flux was estimated from particulate matter flux uncertainty.

The results showed that about half of the standard deviation on the particulate matter transport was linked to the particle concentration uncertainty and that the other half was linked to the velocity uncertainty.

\section{RESULTS}

The first part examines the seasonal variability of the water and PM inflow offshore Marseille.

The second part presents the quantification of the advective exchanges of PM and POC into and out of the Gulf of Lion based on one summer cruise and one winter cruise.

\subsection{Seasonality of the advective fluxes}

\subsubsection{Geostrophic transports of water and PM}

Only part of the Marseille section (stations M3 to M7) was successfully sampled during nine cruises table between June 1993 and July 1996. This transect did not entirely cover the entire width of the Northern Current. We estimated that the M3-M7 section included about half of the along-slope current transport during the summer (Billion) and about two-thirds during the winter (SuiviLion 12). Besides, Conan and Millot (1995) and Conan ed al_(1998) showed that the Northern Current had rapid lateral displacements of its core, up to $20 \mathrm{~km}$. Despite the truncation and the mesoscale fluctuations, these data allowed for an insight into the relative seasonal variations of the fluxes of water and PM entering the Gulf of Lion. For all cruises we used the same level of no motion at $775 \mathrm{~m}$ depth (corresponding to that used for the SuiviLion 12 cruise). Flux modifications, due to the choice of the reference level, were negligible compared to the variations of flux between cruises. For example, the fluxes of water and PM between the M3 and M7 stations for the Billion and SVL12 cruises varied only by $5 \%$ when one changed the depth of the reference level from $775 \mathrm{~m}$ to $1072 \mathrm{~m}$.
Both water and PM net fluxes across the Marseille section showed important seasonal variations, with minimum fluxes from June to September and maximum fluxes from October to May. Water fluxes varied by a minimum of $0.2 \times 10^{6} \mathrm{~m}^{3} \mathrm{~s}^{-1}$ in summer and $1.2 \times 10^{6} \mathrm{~m}^{3} \mathrm{~s}^{-1}$ in winter (figure 5d). Likewise PM fluxes varied between $40 \mathrm{~kg} \mathrm{~s}^{-1}$ in summer and $360 \mathrm{~kg} \mathrm{~s}^{-1}$ in winter (foure 5b). Pelegri and Csanady (1991) defined the advective concentration as an estimate of the velocity-weighted average concentration over a considered section (i.e., ratio of PM flux and water flux). Compared to the simple average concentration, this parameter was more appropriate to assess the seasonal changes. Thus, advective concentration of PM varied only by a factor of $2\left(0.2-0.4 \mathrm{mg} \mathrm{L}^{-1}\right.$; Ggure 5c). Fluctuations of the advective concentrations were smaller than the PM fluxes and were not correlated with them.

\subsubsection{Seasonal current variability}

Current records over six years (1993-2000) were obtained at 500 and $1000 \mathrm{~m}$ depth near station M3 on the Marseille section and at station B4 on the Banyuls section (figure - d ). The mean intensity of the deep currents and their mesoscale variability were characterised by the monthly mean kinetic energy $\left(M K E=\left(\bar{u}^{2}+\bar{v}^{2}\right) / 2\right)$ and eddy kinetic energy $\left(E K E=\left(s_{\mathrm{u}}^{2}+s_{\mathrm{v}}^{2}\right) / 2\right)$, where $\bar{u}$ and $\bar{v}$ are the longitudinal and latitudinal components of the mean velocity, $s_{\mathrm{u}}^{2}$ and $s_{\mathrm{v}}^{2}$ are the corresponding velocity variance. For all records, these parameters clearly showed an annual signal with stronger mean currents and mesoscale variability in winter than in summer; an example is given in figure 6 for the $1000 \mathrm{~m}$ depth time series on the Marseille section. Thus the Billion and SuiviLion 12 cruises were carried out during the two principal hydrologic periods existing in the Gulf of Lion, so much from the point of view of the average current than of the mesoscale variability. The Billion cruise (summer) took place when these two parameters are minimum and conversely for the SuiviLion 12 cruise (winter).

\subsection{Summer period}

\subsubsection{Hydrographic structures during the Billion cruise}

The summer period was characterised by a strong vertical stratification. The four typical water masses of the NW Mediterranean were clearly individualised (December 2-3): MAW, WIW, LIW and DWMW (figure 4d). 
A )

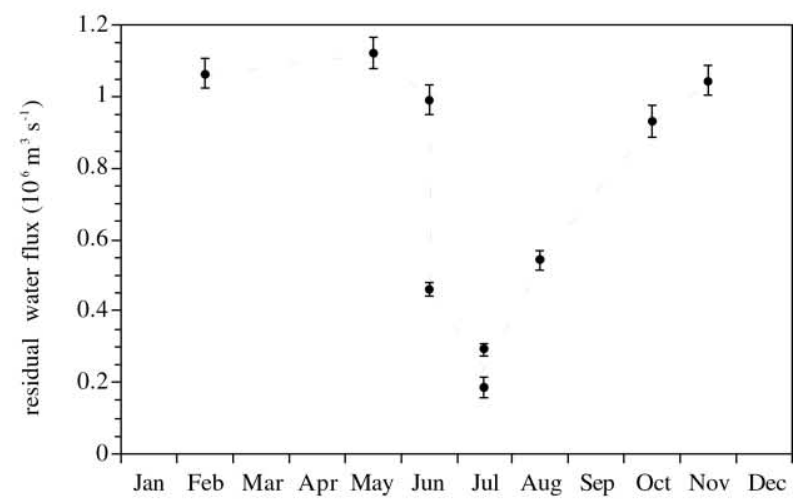

B )

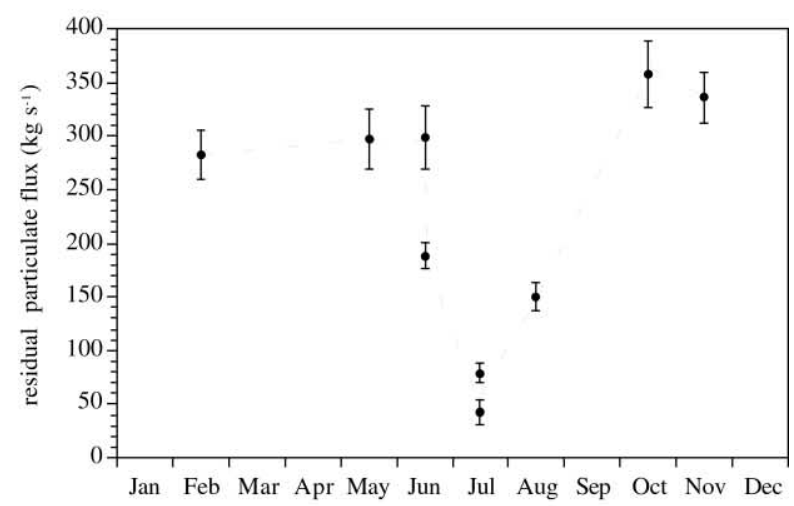

C)

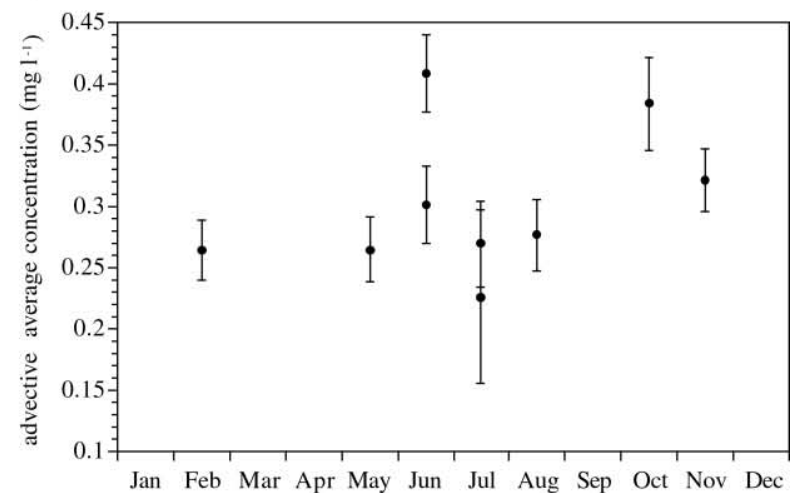

Figure 5. Variation of the geostrophic transports of water (A), PM (B) and advective concentration (C) across the Marseille section between June 1993 and July 1996. The results of the nine different cruises are presented per month in order to apprehend the seasonal variability. Error bars: standard deviation.

The surface layer, mostly composed of MAW, extended down to about $100 \mathrm{~m}$. This layer had a high turbidity which results from an abundance of biogenic matter

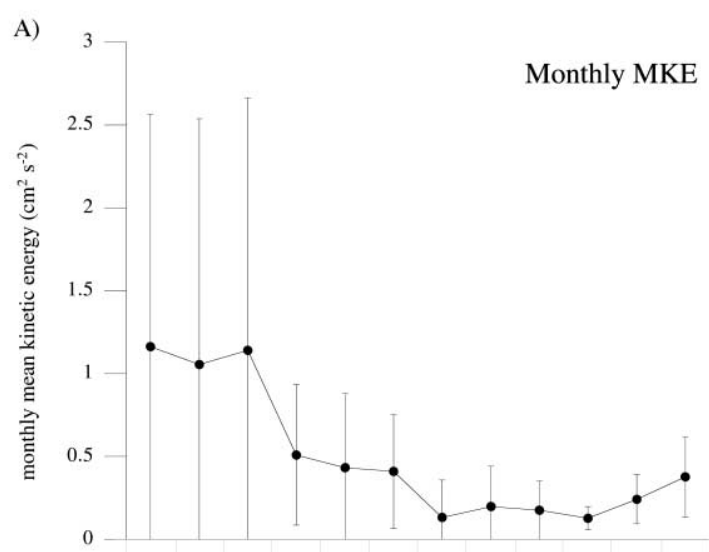

Jan Feb Mar Apr May Jun Jul Aug Sep Oct Nov Dec

B)

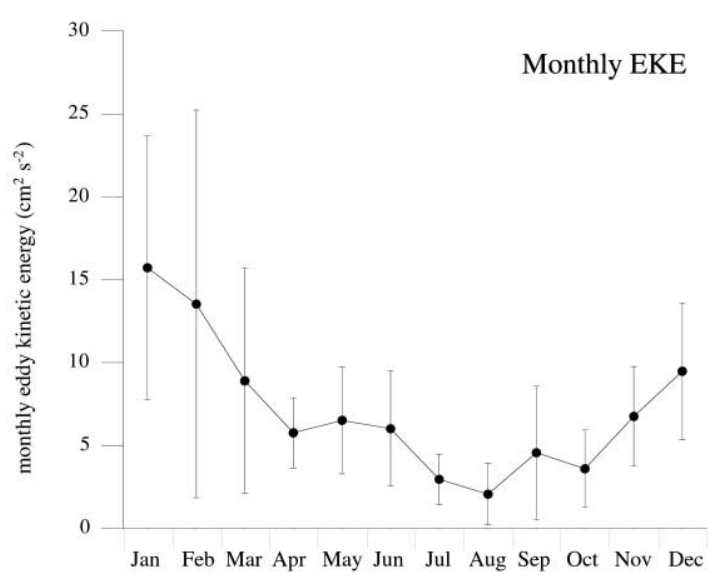

Figure 6. Variations of the monthly mean kinetic energy $\left(M K E=\bar{u}^{2}+\bar{v}^{2}\right) / 2$ and eddy kinetic energy $\left(E K E=\left(s_{\mathrm{u}}^{2}+s_{\mathrm{v}}^{2}\right) / 2\right)$ of the current measured at $1000 \mathrm{~m}$ depth during six years (1993-2000) near station M3. $\bar{u}$ and $\bar{v}$ represent the longitudinal and latitudinal components of the mean velocity, $s_{\mathrm{u}}^{2}$ and $s_{\mathrm{v}}^{2}$ represent the corresponding longitudinal and latitudinal velocity variance. Error bars: $95 \%$ confidence interval.

Copin-Montégut and Copin-Montégut, 1973). WIW were characterised by a temperature minimum located between 100 and $250 \mathrm{~m}$ depth. The warmer and saltier core of LIW was clearly visible between $200 \mathrm{~m}$ and $800 \mathrm{~m}$ along the continental slope on both sides of the gulf (figures $7 d$ and $\mathrm{b}$ ). The seaward rising of the thermo-haline structures and the isopycnals (figure 7 d) formed the typical dome-shaped structure of the Gulf of Lion. The nepheloid structures below the shelf break depth were limited to the upper slope $($ figure $7 d$ ). An 
intense intermediate nepheloid layer reaching $800 \mathrm{~m}$ depth developed on the southwestern Banyuls section, whereas no particular structure appeared on the northeastern Marseille section (Ggure 7d).

\subsubsection{Geostrophic circulation and transports}

The geostrophic velocity field showed a surface circulation which main core, delimited by the $5 \mathrm{~cm} \mathrm{~s}^{-1}$ isotach, extended down to $250 \mathrm{~m}$ depth (figure $8 \mathrm{a}$ ). The core of the cyclonic along-slope flow was pressed on the continental slope, whereas an anti-cyclonic circulation was visible seaward. This counter current was only observed during the summer cruise. The total inflow and outflow of water across the entire section was about $1.66 \pm 0.04 \times 10^{6} \mathrm{~m}^{3} \mathrm{~s}^{-1}$ (Ggure $\left.8 \mathrm{~b}\right)$.

The spatial variations of the advective fluxes of PM and POC were very similar to that of the water flow, for particulate matter concentration varied much less than the current intensity (figure 8d). Consequently, the main inflow of matter occurred on the continental slope off Marseille, and the outflow on the slope off Banyuls. The total inflow of PM was about $371 \pm 12 \mathrm{~kg} \mathrm{~s}^{-1}$, whereas the total outflow was about $396 \pm 13 \mathrm{~kg} \mathrm{~s}^{-1}$. The difference between the inflow and outflow yielded an export of $25 \pm 18 \mathrm{~kg} \mathrm{~s}^{-1}$. About three quarters of the export occurred within the upper layer $\left(\sigma_{\theta}<29\right)$ and the rest within the intermediate layer. A very small import appeared in the deep layer. Using the vertical distribution of POC content for summer (figure 3d), we estimated the POC export to $0.8 \pm 0.2 \mathrm{~kg} \mathrm{~s}^{-1}$.

\subsection{Winter period}

\subsubsection{Hydrographic structures during the SuiviLion 12 cruise}

Unlike the summer period, the water column during winter was more homogeneous (figure 4 b $)$ because of the cooling and mixing of the surface layer (Goures $9 a$ and $b$ ). The seaward rising of the isopycnals was steeper than during summer; they deepened abruptly near the slope and showed on the sea surface seaward (figure 9d). A superficial plume of lower salinity $(<38)$ and higher turbidity was visible along the section off Banyuls fig

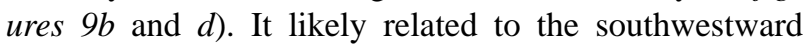
dispersal and dilution of fresh water supplied by the Rhône River, which was in flood at the period of the cruise. The downstream dilution of the LIW core was well evidenced by the decrease in temperature and salinity between the Marseille and the Banyuls sections. Two examples of WIW formation, characterised by the isopycnal cascading of cold surface water, were well traced on the shelf and slope off Banyuls between 100 and $200 \mathrm{~m}$ deep and in the basin off Marseille down to $300 \mathrm{~m}$ depth (figure 9d). The corresponding maxima of turbidity (figure 9d) and fluorescence (data not shown) revealed a rapid downward transfer of surface particulate matter. The export of particulate matter from the shelf due to cascading was more intense along the Banyuls section, where the coldest waters are observed, than on the section off Marseille.

\subsubsection{Geostrophic circulation and transports}

The Northern Current presented a well delimited core about $60 \mathrm{~km}$ width and $300 \mathrm{~m}$ thick (figure 10a), entering the Gulf of Lion off Marseille and leaving it off Banyuls. The intensity of inflow and outflow of water across the entire section was about $1.78 \pm 0.05 \times 10^{6} \mathrm{~m}^{3} \mathrm{~s}^{-1}$ (Goure 20b).

The PM fluxes foure 10 indicated a total inflow of $412 \pm 13 \mathrm{~kg} \mathrm{~s}^{-1}$ and a total outflow of $522 \pm 17 \mathrm{~kg} \mathrm{~s}^{-1}$. The difference between the inflow and outflow yielded a PM export of $110 \pm 20 \mathrm{~kg} \mathrm{~s}^{-1}$. Nine tenths of the total export occurred in the surface layer, mostly within the cold water layer cascading off Banyuls, and the rest in the intermediate layer. No imbalance appeared in the deep layer. Using the vertical distribution of POC content for winter and an extrapolated value of $8 \%$ below $1000 \mathrm{~m}$ depth (Goure 3d), we estimated the POC export to $12.8 \pm 0.5 \mathrm{~kg} \mathrm{~s}^{-1}$.

\section{DISCUSSION AND CONCLUSION}

\subsection{Fluxes of particulate matter into the Gulf of Lion}

The low seasonal variation of the advective concentrations across the section off Marseille and their absence of covariation with the PM fluxes (fgure 5d and B ) suggest that the PM flux entering the Gulf of Lion is predominantly related to the variability of the Northern Current water transport rather than to variations of the PM 
A )

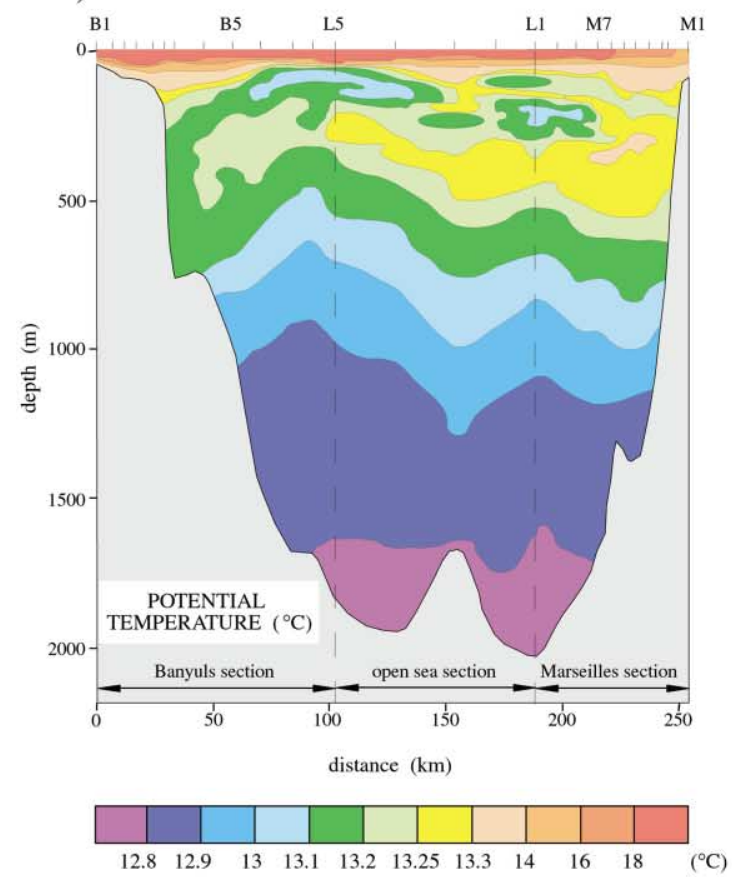

B )
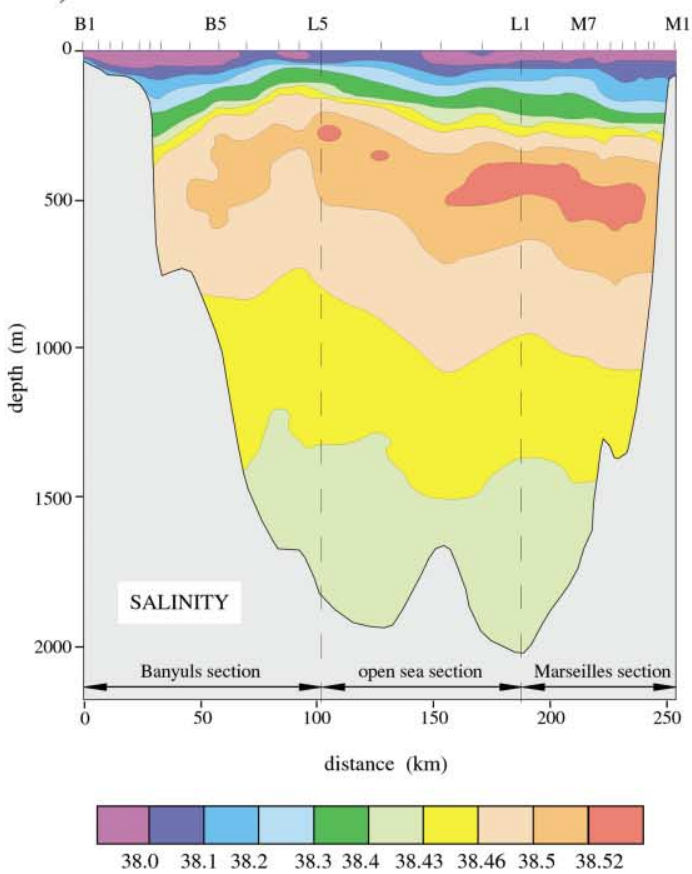

C)

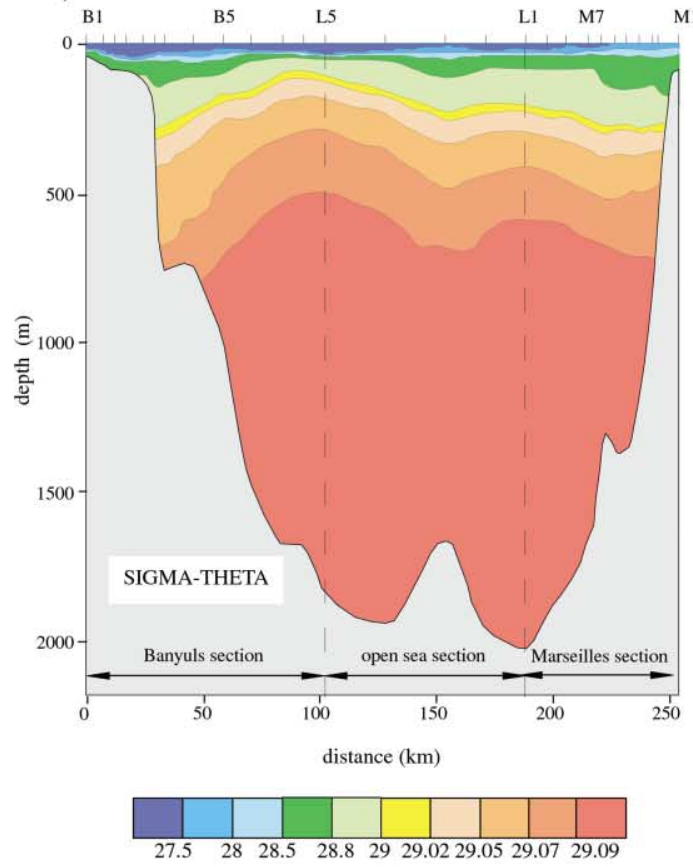

D )

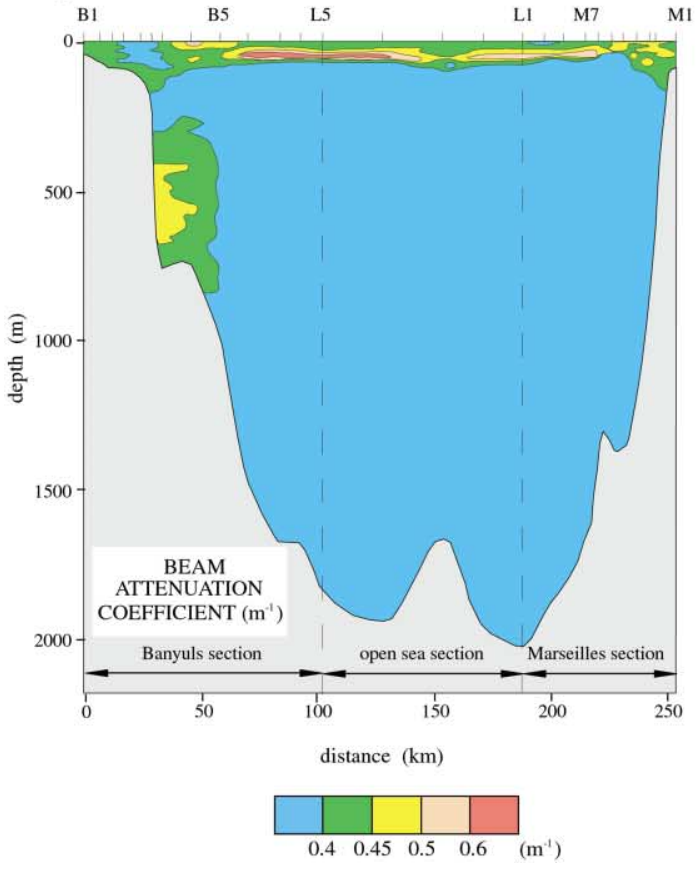

Figure 7. Along-track sections of potential temperature (A), salinity (B), potential density anomaly (C) and beam attenuation coefficient (D) during the Billion cruise (July 1996). Station position is along top, depth scale along left side, and distance from southwestern edge. 

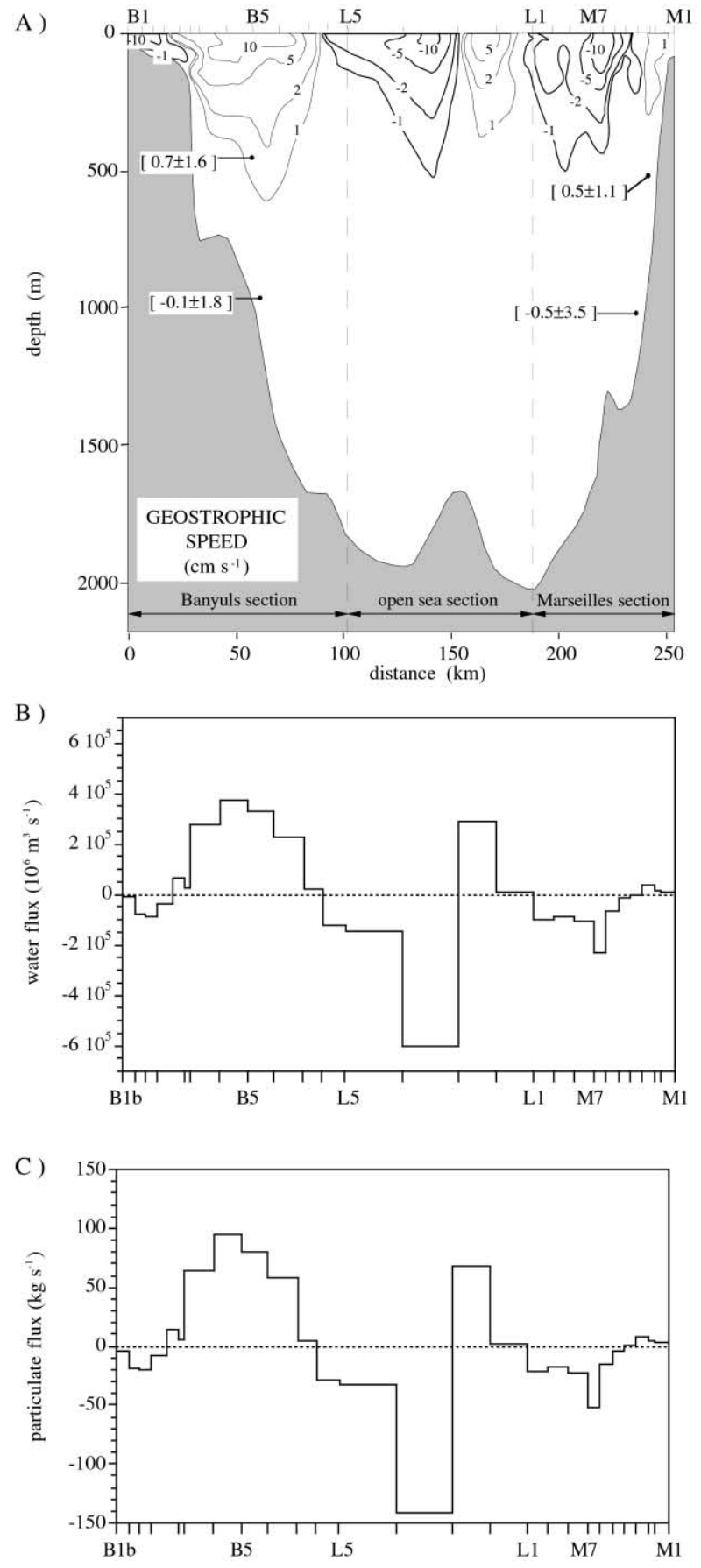

Figure 8. Contours of geostrophic velocity along the section and low-pass monthly mean currents in square brackets for comparison, during the Billion cruise in July 1996 (A). Fluxes of water (B) and PM (C) across the section. Inflows are negative and outflows are positive. concentration in the water column. The seasonal variation of the inflow of water off Marseille, with low flux in summer, is consistent with previous works Conan and Millot 1995: Conan et al. 1998. The seasonal intensification of the mean current intensity and of the mesoscale activity (Goure 6 ) are also in agreement with other observations made in the Gulf of Lion Durrieu de Madron et al. 1999) and in the Ligurian Sea (Sammari et al. 1995:Albérola et al. 1995. This annual cycle relates to the winter intensification of the general circulation of the northwestern Mediterranean (Millot.1999).

Sempéré et al_(2000) inferred a logarithmic relation between the PM concentration and the water flux of the Rhône River. Using this relation with the water fluxes of the Rhône River between 1987 and 1999, we obtain a mean river PM flux of $77 \mathrm{~kg} \mathrm{~s}^{-1}$ for the summer period (June-September) and of $373 \mathrm{~kg} \mathrm{~s}^{-1}$ for the rest of the year (October-May). It appears therefore that the inflow of PM advected by the Northern Current into the Gulf of Lion is comparable to the average Rhône River inputs.

\subsection{Why is the export from the Gulf of Lion higher in winter than the summer?}

The increase of the PM transport off Banyuls both in summer and in winter indicates that during its cyclonic transit along the Gulf of Lion margin, the slope waters conveyed by the Northern Current are enriched in particles. The budget of the advective fluxes for the Billion and SuiviLion 12 cruises indicates that higher export occurs in winter than in summer. The winter/spring increase of the export likely relates to an intensification of the inputs of particulate matter to the Gulf of Lion.

Indeed, allochthonous particulate matter inputs from river Pont 1997) and the atmosphere Lüye-Pilot and Martin 1996, as well as autochthonous inputs from the biological production Lefevre et_al__1997) show a seasonal trend with larger inputs during winter/spring than in summer. Besides, several dynamical processes, responsible for the lateral transport of particulate matter from the shelf to the slope, occur or culminate in winter/early spring. The cascading of cold shelf water that is traced only during the winter cruise, exports large amount of PM on the western part of the Gulf of Lion (figures 9 and d). In a modelling study of the exchanges of water and nutrients between the shelf and the slope waters, TusseamVillemin et al. (1998) emphasised that the dense water 
A )
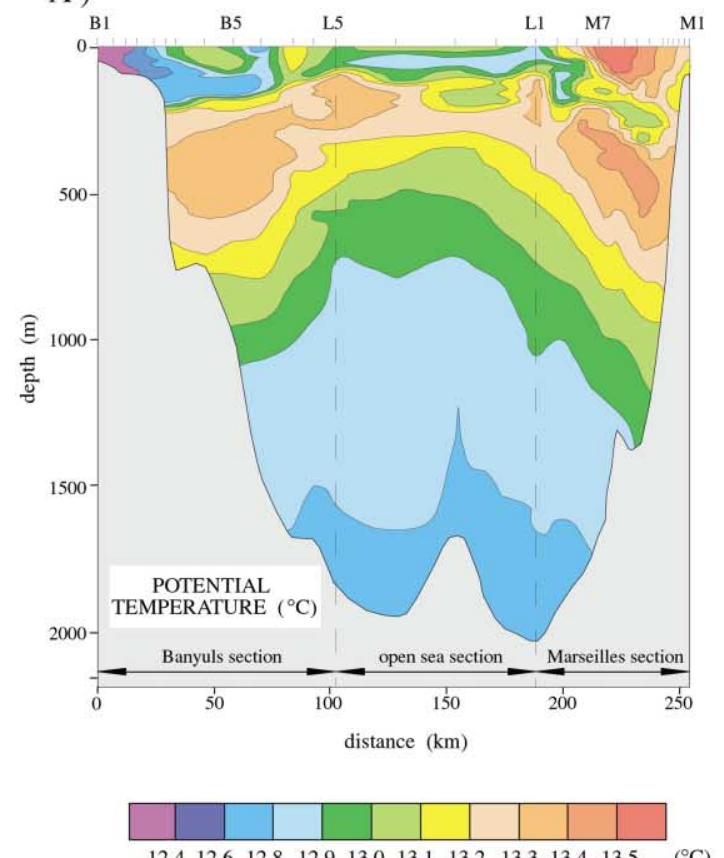

$\begin{array}{llllllllllll}12.4 & 12.6 & 12.8 & 12.9 & 13.0 & 13.1 & 13.2 & 13.3 & 13.4 & 13.5\end{array}$ $\left({ }^{\circ} \mathrm{C}\right)$
B )
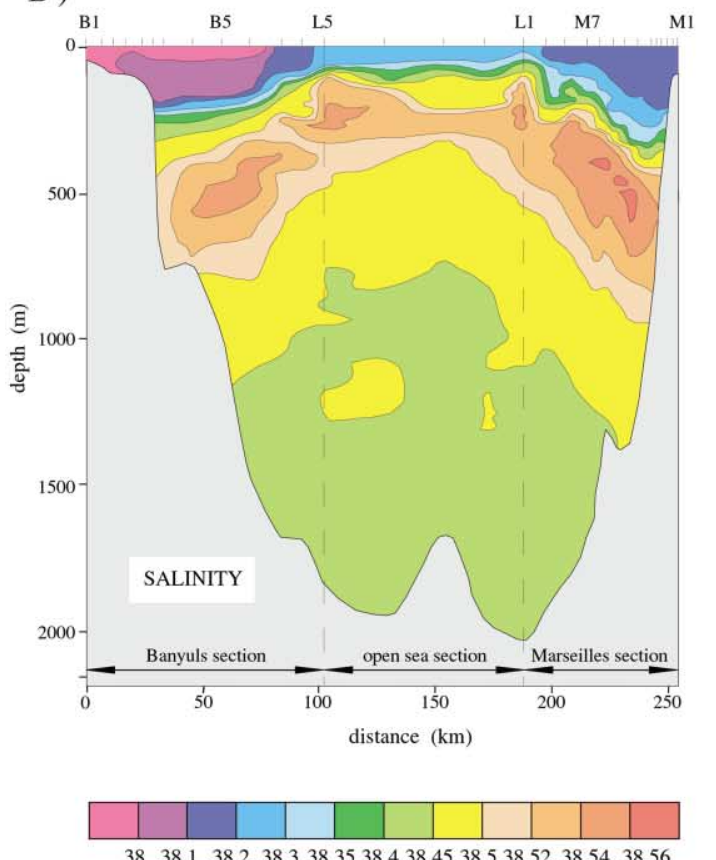

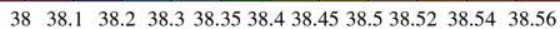

C )

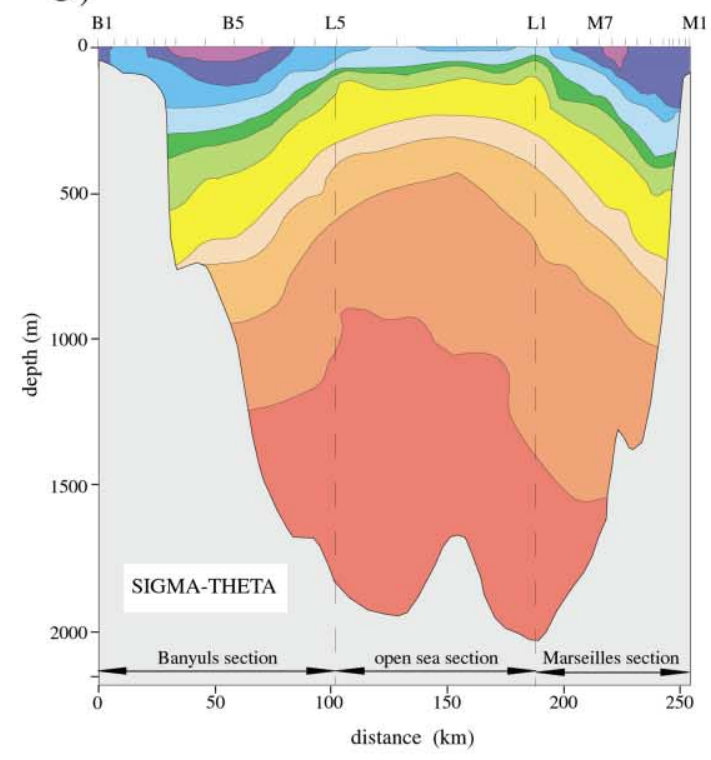

\begin{tabular}{llllll|l|l|l|l|l}
28.7 & 28.8 & 28.9 & 29 & 29.0329 .0629 .08 & 29.08529 .09 & 29.095
\end{tabular}
D )

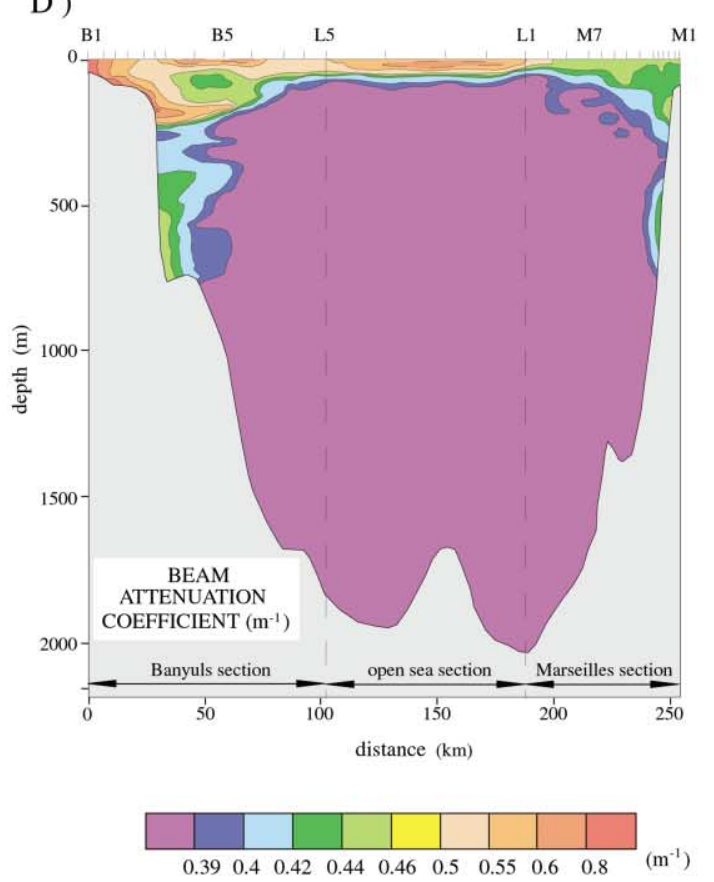

Figure 9. Along-track sections of potential temperature (A), salinity (B), potential density anomaly $(\mathbf{C})$ and beam attenuation coefficient $(\mathbf{D})$ along the section during the SuiviLion 12 cruise (February 1995). Station positions are along top, depth scale along left side, and distance from southwestern edge. 

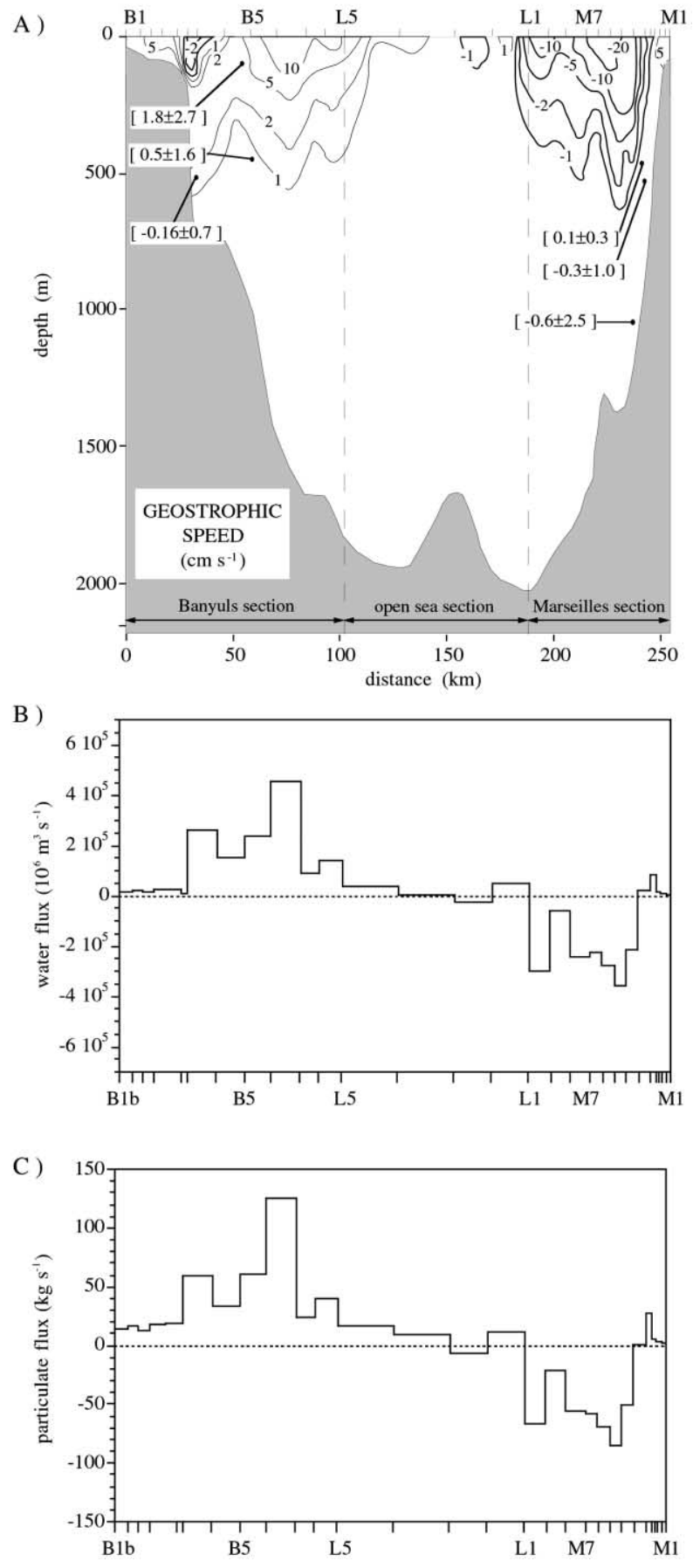

Figure 10. Contours of geostrophic velocity along the section and low-pass monthly mean currents in square brackets for comparison, during the SuiviLion 12 cruise in February 1995 (A). Fluxes of water (B) and PM (C) across the section. Inflows are negative and outflows are positive. cascading in winter is responsible for a large part of the export of nutrients from the Gulf of Lion. Durrieu de Madron et al_(1999) also described the effect of the meanders of the Northern Current that produced downslope export of PM by turbulent mixing. Their magnitude, characterised by the meso-scale variability of the along-slope current, is maximum in winter (fgure 6). Another potential source of PM comes from the particle resuspension on the shelf and slope. In the absence of direct observations of resuspension, we can only suppose that resuspension would preferentially occur in winter when the currents are faster and the storms more frequent. This seasonal intensification of the inputs and of the shelf-slope exchanges processes was also put forward by Monaco et al $(1990,1999)$ to explain the recurrent increase of vertical particle fluxes on the continental slope during winter.

\subsection{Comparison with typical export mechanisms}

The downstream increase of the advective transport of $\mathrm{PM}$ is assumed to result from a transfer of matter from the shelf to the deep ocean. We try to assess the export associated with two processes that are of major importance on the Gulf of Lion shelf, namely the bottom Ekman transport during summer and the dense water cascading during winter.

\subsubsection{Bottom Ekman transport during summer}

Durrieu de Madron and Panouse (1996) showed that the along-isobath circulation on the shelf produces a crossshelf transport in the Ekman bottom layer. Given that the circulation on the outer shelf is generally cyclonic, the Ekman transport displaces bottom waters and particulate matter seaward. It is possible from the parameterisation of the Ekman transport (Huthnance, 1995) to estimate the export of PM associated with this process. The flux of $P M$ exported by the bottom Ekman transport may be written as follows: $F_{\mathrm{E}}=(\tau / \rho f) L C_{\mathrm{PM}}$, where $\tau$ represents the shear stress of the current at the bottom, $\rho\left(1030 \mathrm{~kg} \mathrm{~m}^{-3}\right)$ the density of the water, $f\left(10^{-4} \mathrm{~s}^{-1}\right)$ the Coriolis parameter, $L\left(2 \times 10^{5} \mathrm{~m}\right)$ the length of the Gulf of Lion at the shelf break depth, and $C_{\mathrm{PM}}\left(5 \times 10^{-4} \mathrm{~kg} \mathrm{~m}^{-3}\right)$ the average concentration of PM. The bottom shear stress can be estimated from the quadratic law: $\tau=\rho C_{\mathrm{d}} V_{\mathrm{b}}^{2}$, where $V_{\mathrm{b}}$ $\left(5 \times 10^{-2} \mathrm{~m} \mathrm{~s}^{-1}\right)$ is the speed of the current at the bottom and $C_{\mathrm{d}}\left(2 \times 10^{-3}\right)$ the drag coefficient. The flux of 
particulate matter $F_{\mathrm{E}}$, calculated with typical parameter values of the Gulf of Lion, is estimated as $5 \mathrm{~kg} \mathrm{~s}^{-1}$.

\subsubsection{Dense water cascading during winter}

Winter dense water formation on the Gulf of Lion shelf results from the evaporation and the cooling of surface waters by dry and cold northern winds (Mistral, Tramontana). This newly formed water mass cascades from the shelf down the slope until it reaches its buoyancy equilibrium at a few hundred meters depth generally. Huthnance (1995) proposed a scaling of the cascading process. We use it to quantify the export of particulate matter associated with this flow:

$$
F_{c}=\left(L h C_{P M} / 0.6 f\right)\left(g \alpha / \rho C_{p}\right)^{2 / 3}\left(H^{2} / W_{s}\right)^{1 / 3}
$$

where $g\left(9.8 \mathrm{~m} \mathrm{~s}^{-2}\right)$ is the gravitational acceleration, $\alpha$ $\left(2 \times 10^{-4 \circ} \mathrm{C}^{-1}\right)$ the thermal expansion coefficient of the water, $C_{\mathrm{p}}\left(4 \times 10^{3} \mathrm{~J} \mathrm{~kg}^{-1}{ }^{\circ} \mathrm{C}^{-1}\right)$ the specific heat of water, $h(100 \mathrm{~m})$ the average water depth on the shelf, $H$ $\left(\mathrm{W} \mathrm{m}^{-2}\right)$ the heat loss from the surface and $W \mathrm{~s}$ $\left(6.5 \times 10^{4} \mathrm{~m}\right)$ the shelf width. As previously $\rho$ $\left(1030 \mathrm{~kg} \mathrm{~m}^{-3}\right)$ indicates the density of the water, $L$ $\left(2 \times 10^{5} \mathrm{~m}\right)$ the length of the Gulf of the Lions at the shelf break depth and $C_{\mathrm{PM}}\left(5 \times 10^{-4} \mathrm{~kg} \mathrm{~m}^{-3}\right)$ the average concentration of PM. Using an average heat flux (loss) of $160 \mathrm{~W} \mathrm{~m}^{-2}$ computed for a period including the Suivilion 12 cruise and the previous month (data from Météo France), the calculated flux of matter associated with the cascading of winter cold water is estimated at $74 \mathrm{~kg} \mathrm{~s}^{-1}$.

These calculations show that the Ekman transport has a lower export capacity than the dense water cascading, and that the order of magnitude of these transports is comparable to our experimental estimations of the PM exported by the Northern Current out of the Gulf of Lion. Such estimates are not representative of exceptional events, such as the intense dense water cascading of shelf water observed in 1999 and that is believed to occur with a decennial periodicity Béthoux et al. 2000)

\subsection{Comparison of horizontal and vertical particulate fluxes}

Vertical particulate fluxes were measured with sediment traps at 500 and $1000 \mathrm{~m}$ depth within the Planier canyon (near station M3) and the Lacaze-Duthiers canyon (near station B4) (figure d). The sampling interval varies between 15 days and one month. We estimate the average
PM and POC fluxes for the four traps during the one-month periods including the SuiviLion 12 and Billion cruises. The average PM and POC fluxes measured during February 1995 are similar to those obtained during July 1996 . They are about $1.4 \times 10^{3} \mathrm{mg} \mathrm{m}^{-2}$ per day and $31 \mathrm{mg} \mathrm{m}^{-2}$ per day respectively.

In order to compare these latter fluxes with the horizontal export of PM and POC from the Gulf of Lion, we suppose, as previously, that the exported material entirely comes from the shelf and is advected homogeneously through the border between the shelf and the slope. The surface of this limit is calculated as $L \times h$ $\left(2 \times 10^{7} \mathrm{~m}^{2}\right)$, where $L\left(2 \times 10^{5} \mathrm{~m}\right)$ is the length and $h$ $(100 \mathrm{~m})$ the average water depth of the shelf edge. The horizontal fluxes of PM and POC per unit area for the Suivilion 12 cruise are thus $4.8 \times 10^{5} \mathrm{mg} \mathrm{m}^{-2}$ per day and $5.5 \times 10^{4} \mathrm{mg} \mathrm{m}^{-2}$ per day respectively. The horizontal fluxes of PM and POC per unit area for the Billion cruise are $1.1 \times 10^{5} \mathrm{mg} \mathrm{m}^{-2}$ per day and $3.5 \times 10^{3} \mathrm{mg} \mathrm{m}^{-2}$ per day respectively. These crude estimates indicate that the horizontal export of PM and POC is about two orders of magnitude higher than the vertical particulate fluxes. This result is coherent with the estimate of Puig et al_(2000). From a one-year long experiment in the Foix canyon on the Barcelona continental margin, they showed that the horizontal fluxes of suspended particles, calculated directly from current and light transmission observations, were 27 to 360 times higher than the settling particle fluxes measured at the same time with sediment traps. The difference between the horizontal and the vertical particulate fluxes is not surprising taking into account the fact that the horizontal component of the currents is generally 100 times higher than the vertical component. All these results markedly underline the importance of the horizontal export.

\section{Acknowledgements}

This research has been undertaken in the framework of the Programme national d'océanographie côtière (PNOC) and the MAST-III-ELOISE European Union Metro-Med Project. We acknowledge the support from the CNRS-INSU, the Ifremer and the European Commission's Marine Science and Technology (MAST) programme under contract MAS3-CTP96-0049. We are grateful to P. Kerhervé and J.L. Blazi for performing the water sample analyses. We warmly thank the officers and crews of RVs L'Europe from Ifremer, and Tethys II from CNRS-INSU for their assistance. 


\section{REFERENCES}

Albérola, C., Millot, C., Font, J., 1995. On the seasonal and mesoscale variabilities of the Northern Current during the PRIMO-0 experiment in the western Mediterranean Sea. Oceanol. Acta 18, 163-192.

Bauer, J.E., Druffel, E.R.M., 1998. Oceans margins as a significant source of organic matter to the deep open ocean. Nature 392, $482-485$.

Beckers, J.M., Brasseur, P., Nihoul, J.C.J., 1997. Circulation of the western Mediterranean: from global to regional scales. Deep-Sea Res. II 44, 531-549.

Béthoux JP, Durrieu de Madron X, Nyffeler F., Taillez D., 2000. Dense water formation in western Mediterranean: peculiar 1999 event and climatic variability since 1970. EGS 2000, Nice.

Bouloubassi, I., Lipiatou, E., Saliot, A., Tolosa, I., Bayona, J.M., Albaigés, J., 1997. Carbon sources and cycle in the western Mediterranean - the use of molecular markers to determine the origin of organic matter. Deep-Sea Res. II 44, 781-800.

Calmet, D., Fernandez, J.M., 1990. Cesium distribution in the northwest Mediterranean seawater, suspended particles and sediments. Cont. Shelf Res. 10, 895-914.

Cauwet, G., 1981. Non-living particulate organic matter. In: Duursma, E.K., Dawson, R. (Eds.), Marine organic chemistry. Elsevier, Amsterdam.

Conan, P., Millot, C., 1995. Variability of the Northern Current off Marseille, western Mediterranean Sea, from February to June 1992. Oceanol. Acta 18, 193-205.

Conan, P., Pujo-Pay, M., Raimbault, P., Leveau, M., 1998. Variabilité hydrologique et biologique du Golfe du Lion. Transports en azote et productivité potentielle. Oceanol. Acta 21, 751-765.

Copin-Montégut, C., Copin-Montégut, G., 1973. Étude chimique des particules en suspension dans l'eau de mer en Méditerranée occidentale. Thal. Jugosl. 9, 39-45.

Durrieu de Madron, X., Nyffeler, F., Godet, C.H., 1990. Hydrographic structure and nepheloid spatial distribution in the Gulf of Lion continental margin. Cont. Shelf Res. 10, 915-929.

Durrieu de Madron, X., Panouse, M., 1996. Transport de matière particulaire en suspension sur le plateau continental du golfe du Lion. Situation hivernale et estivale. C. R. Acad. Sci. IIA 322, 1061-1070.

Durrieu de Madron, X., Radakovitch, O., Heussner, S., Löye-Pilot, M.D., Monaco, A., 1999. Role of the climatological and current variability on shelf-slope exchanges of particulate matter: evidence from the Rhône River continental margin (NW Mediterranean). Deep-Sea Res. I 46, 1513-1538.

Feely, A. Trefry, J.H., Monger, B., 1991. Particles sampling and preservation. Marine particles: analysis and characterization. Hurd, D.C., Spencer, D.W. (Eds.). Geophys. Monogr. Ser. 63, 5-22.

Got, H., Aloisi, J.C., 1990. The Holocene sedimentation on the Gulf of Lion margin: a quantitative approach. Cont. Shelf Res. 10, 841-856.

Grilli, F., Pinardi, N., 1998. The computation of Rossby radii of deformation for the Mediterranean Sea. Mediterranean targeted project newsletter no. 6 , p. 4 .
Guillén, A., Palanques, A., Puig, P., Durrieu de Madron, X., Nyffeler, F., 2000. Field calibration of optical sensors for measuring suspended sediment concentration in the western Mediterranean. Sci. Mar. 64, 427-435.

Hall, J., Smith, S., 1996. First report of the JGOFS/LOICZ continental margins task team. LOICZ reports and studies no. 7, JGOFS report no. 21.

Hauser, D., Dupuis, H., Durrieu de Madron, X., Estournel, C., Flamant, C., Pelon, J., Queffeulou, P., Lefèvre, J.M., 2000. La campagne Fetch : une expérience pour l'étude des échanges océan/atmosphère dans les conditions côtières du golfe du Lion. La Météorologie 8, 14-31.

Henry, F., Jeandel, C., Dupré, B., Minster, J.F., 1994. Particulate and dissolved $\mathrm{Nd}$ in the western Mediterranean Sea: sources, fate and budget. Mar. Chem. 45, 283-306.

Heussner, S., Ratti, C., Carbonne, J., 1990. The PPS 3 time-series sediment traps and the trap sample processing techniques used during the Ecomarge experiment. Cont. Shelf Res. 10, 943-958.

Heussner, S., Calafat, A., Palanques, A., 1996. Quantitative and qualitative features of particle fluxes in the North Balearic basin. In: Canals, M., Casamor, J.L., Cacho, I., Calafat, A.M., Monaco, A. (Eds.), Euromarge-NB final report, MAST II program, EU, Vol. IIIB. RGMG-University of Barcelona, Barcelona, pp. 43-66.

Hofman, E.E., Worley, S.J., 1986. An investigation of the circulation of the Gulf of Mexico. J. Geophys. Res. Oceans 91, 14221-14236.

Huthnance, J.M., 1995. Circulation, exchange and water masses at the ocean margin: the role of physical processes at the shelf edge. Prog. Oceanogr. 35, 353-431.

Lefevre, D., Minas, H.J., Minas, M., Robinson, C., Williams, P.J. Le B., Woodward, E.M.S., 1997. Review of gross community production, primary production, net community production and dark community respiration in the Gulf of Lion. Deep-Sea Res. II 44, 801-832.

Liu, K.K., Atkinson, L., Chen, C.T.A., Gao, S., Hall, J., MacDonald, R.W., Talaue McManus, L., Quiñones, R., 2000. Exploring continental margin carbon fluxes on a global scale. EOS, Transactions. Am. Geophys. Union 81, 641-644.

Löye-Pilot, M.D., Martin, J.M., 1996. Saharan dust input to the western Mediterranean an eleven years records in Corsica. In: Guerzoni, S., Chester, R. (Eds.), The impact of African dust across the Mediterranean. Kluwer, Amsterdam, pp. 191-199.

Millot, C., 1990. The Gulf of Lion' hydrodynamics. Cont. Shelf Res. 10, 885-894.

Millot, C., 1999. Circulation in the Western Mediterranean Sea. J. Mar. Syst. 20, 423-442.

Monaco, A., Courp, T., Heussner, S., Carbonne, J., Fowler, S.W., Deniaux, B., 1990. Seasonality and composition of particulate fluxes during Ecomarge-I, western Gulf of Lion. Cont. Shelf Res. 10, 959-988.

Monaco, A., Durrieu de Madron, X., Radakovitch, O., Heussner, S., Carbonne, J., 1999. Origin and variability of downward biogeochemical fluxes on the Rhône River continental margin (NW Mediterranean). Deep-Sea Res. I 46, 1483-1512.

Morel, A., André, J.M., 1991. Pigment distribution and primary production in the western Mediterranean as derived and modeled 
from coastal zone color scanner observations. J. Geophys. Res. Oceans 96, 685-698.

Pond, S., Pickard, G.L., 1983. Introductory dynamical oceanography. Pergamon Press, Oxford.

Pont, D., 1997. Les débits solides du Rhône à proximité de son embouchure : données récentes (1994-1995). Rev. Géogr. Lyon 72, 1-97.

Press, W.H., Flannery, B.P., Teukolsky, S.A., Vetterling, W.T., 1989. Numerical recipes, the art of scientific computing. Cambridge University Press, Cambridge.

Puig, P., Palanques, A., 1998. Nepheloid structure and hydrographic control in the Barcelona continental margin, eastern Spain. Mar. Geol. 149, 39-54.

Puig, P., Palanques, A., Guillén, J., García-Ladona, E., 2000. Deep slope currents and suspended particle fluxes in and around the Foix submarine canyon (NW Mediterranean). Deep-Sea Res. I 47, 343-366.

Sammari, C., Millot, C., Prieur, L., 1995. Aspects of the seasonal and mesoscale variabilities of the Northern Current in the western Mediterranean Sea inferred from the Prolig-2 and Pros-6 experiments. Deep-Sea Res. I 42, 893-917.
Sempéré, R., Charrière, B., Van Wanbecke, F., Cauwet, G., 2000. Carbon inputs of the Rhône River to the Mediterranean Sea: biogeochemical implications. Glob. Biogeochem. Cycles 14, 669-681.

Sokal, R.R., Rohlf, F.J., 1981. Biometry. Freeman W.H., and Co., New York, NY.

Tusseau-Vuillemin, M.H., Mortier, L., Herbaut, C., 1998. Modelling nitrate fluxes in an open coastal environment (Gulf of Lion): transport versus biogeochemical processes. J. Geophys. Res. Oceans 103, 7693-7708.

Yoro, S.C., Sempéré, R., Turley, C., Unanue, M.A., Durrieu de Madron, X., Bianchi, M., 1997. Cross-slope variations of organic carbon and bacteria in the Gulf of Lion in relation to water dynamics (Northwestern Mediterranean). Mar. Ecol. Prog. Ser. 161, 255-264.

Zuo, Z., Eisma, D., Berger, G.W., 1991. Determination of sediment accumulation and mixing rates in the Gulf of Lion, Mediterranean Sea. Oceanol. Acta 14, 253-262.

Zuo, Z., Eisma, D., Gieles, R., Beks, J., 1997. Accumulation rates and sediment deposition in the northwestern Mediterranean. Deep Sea Res. II 44, 597-609. 